\title{
Irrigation activities affecting arsenic mobilization in topsoil in Datong Basin, northern China
}

\author{
Z.Y. Xiao \& X.J. Xie \\ State Key Laboratory of Biogeology and Environmental Geology \& School of Environmental Studies, \\ China University of Geosciences, Wuhan, P. R. China
}

\begin{abstract}
The use of high arsenic groundwater for irrigation has been prevailed for decades in the Datong Basin. To reveal the characteristics of As mobilization in topsoil under irrigation activities, a filed plot-experiment has been conducted in the central area of Datong Basin. The irrigation activities promoted Fe(II) oxidizing to $\mathrm{Fe}(\mathrm{III}$ ) (oxyhydr)oxide, and As was adsorbed on Fe(III) (oxyhydr)oxide. As a result, the contents of As and Fe in sediments increased finally. Meanwhile, the irrigation activities led to the increase of soil salinity. Moreover, inverse geochemical modeling suggested that geochemical process was conducted during field experiment. The results illustrated temporal changes in As concentration under irrigation activities.
\end{abstract}

\section{INTRODUCTION}

Arsenic (As) contamination of water and soil has been recognized as a grand challenge for humans as well as for fauna and flora (Mandal \& Suzuki, 2002). The speciation of arsenic is affected by multiple geochemical processes. Previous studies have demonstrated that the migration and transformation of As in aquifers are controlled by multiple geochemical processes, closely associated with redox environment and Fe (oxyhydr)oxide (Postma et al., 2012). Plenty of agricultural irrigation activities have prevailed in the Datong basin in the past decades. Although high As groundwater in Datong Basin was widely documented in recent years, there are few data of unsaturated As concentrations of soil and soil water. Therefore, the aims of this study are: 1) delineate the composition of soil water and soil sediments under irrigation; 2) understand the arsenic fate in topsoil during irrigation activities.

\section{MATERIAL AND METHODS}

\subsection{Field experiment}

The field experiment of 2015 and 2016 has been lasting for 3 stages respectively, pre-irrigation before Aug. 10th, irrigation from Aug. 11th to 18th, and post irrigation from Aug. 19th to 24th, 2015, and pre-irrigation before Sep. 5th, irrigation from Sep. 6th to 14th, and post irrigation from Sep 15 th to 17 th, 2016. The soil water samples have been tapped from $0.5 \mathrm{~m}$ and soil sediments samples have been excavated twice in 2015 with the interval of $0.2 \mathrm{~m}$ from the depths 0 to $2.0 \mathrm{~m}$ on Aug. 10th and Aug. 24th. The irrigated water was from the shallow groundwater aquifer with high As concentration far from the irrigation filed. The chemical and physical parameters including temperature,
$\mathrm{pH}, \mathrm{EC}$ and ORP values were measured on site using an $\mathrm{HACH}$ portable meter calibrated before use.

\subsection{Laboratory analysis}

Concentrations of total As were analyzed by hydride generation atomic fluorescence spectrometry (HGAFS) (AFS-820, Titan). The major cations were determined by ICP-AES (IRIS Intrepid II XSP) and anion concentrations were determined using ion chromatography (IC) (Metrohm 761 Compact). The total As concentrations in the soil samples were dissolved by aqua regia and determined by HG-AFS while total $\mathrm{Fe}$ concentrations in the soil samples were digested in the Muffle furnace for $8 \mathrm{~h}$ first and dissolved by $\mathrm{HCl}$ with $100^{\circ} \mathrm{C}$ for $6 \mathrm{~h}$, finally measured using o-phenanthroline spectrophotometric analysis method by the spectrophotometry HACH, DR2800.

\section{RESULTS AND DISCUSSION}

\subsection{Hydrochemistry}

The EC values from the soil samples show the tendency that the conductivity values increase with irrigation on-going (Fig. 1a), while As concentrations show an opposite trend (Fig. 1b).

Moreover, the plots of 2016 vs. 2015 clearly indicate that irrigation activities would result in the salinization and the accumulation of As in topsoil. Intensive extraction of groundwater for agricultural activities and domestic purpose over decades may have made irrigation return flow and salt flushing water become the source of recharge for aquifers at Datong Basin. Meanwhile, the high rate of the evaporation aggravated the phenomena of salinization so that the soil water presented high concentration of salt as well as the groundwater sample of shallow aquifer. 

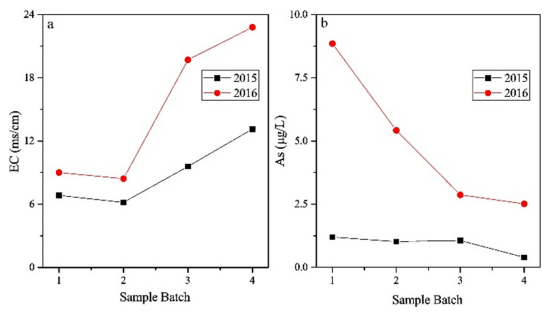

Figure 1. Plots of EC values of $0.5 \mathrm{~m}$ from soil water samples of each batch ( 1 for Inirri-1, 2 for Inirri-2, 3 for Postirri-1 and 4 for Postirri-2).

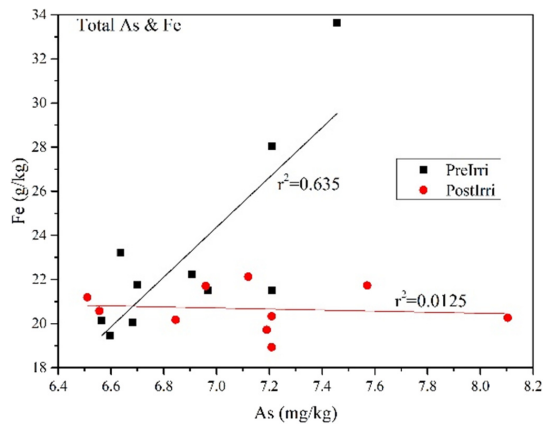

Figure 2. Correlations between total As vs. total Fe from soil sediments analysis.

\subsection{As in sediments}

Geochemical analysis on sediment samples was conducted to exploit potential effects of the forms of As and $\mathrm{Fe}$ minerals on As mobilization. Before irrigation activities conducting, the concentrations of total As and $\mathrm{Fe}$ show a positive correlation (Figure 2). However, the concentrations of total As and Fe reveal a negative correlation (Figure 2), suggesting that with irrigation on-going As has decoupled with Fe gradually.

\subsection{Inverse geochemical modeling}

Inverse geochemical modeling was made to further analyze the impact of irrigation on As mobilization by code PHREEQC-3 with the wateq4f.database (Charlton \& Parkhurst 2011). The soil water chemical compositions of $\mathrm{HCO}_{3}^{-}, \mathrm{SO}_{4}^{2-}, \mathrm{Cl}^{-}, \mathrm{Ca}^{2+}, \mathrm{Mg}^{2+}$, $\mathrm{Na}^{+}, \mathrm{Fe}$, as well as $\mathrm{pH}$ were used in the modeling. To ensure the charge balance satisfy the uncertainty limit, the composition $\mathrm{Cl}^{-}$was chose to adjust the balance. The mineral phases of the modeling were chose from the XRD results and the SI (saturation indices) numbers calculated by PHREEQC-3. Soil water samples of 2015 were chosen for the modeling. The summary of the most optimum choices of the inverse geochemical modeling with phase mole transfers of the minerals and gases is given in Table 1. Modeling results suggest that gypsum and siderite are generally dissolving while calcite, $\mathrm{Fe}(\mathrm{OH})_{3}(\mathrm{a}), \mathrm{FeS}(\mathrm{ppt})$, and $\mathrm{CO}_{2}(\mathrm{~g})$ are precipitating. However, $\mathrm{H}_{2} \mathrm{~S}(\mathrm{~g})$ are changed with irrigation activities on-going. The dissolution of $\mathrm{H}_{2} \mathrm{~S}(\mathrm{~g})$ forms
Table 1. The results of inverse geochemical inverse modeling of soil water evolution under irrigation activities.

\begin{tabular}{lcccc}
\hline \multicolumn{5}{c}{ Phase mole transfers } \\
\cline { 2 - 5 } Minerals & $\begin{array}{c}\text { PreIrri to } \\
\text { InIrri1 }\end{array}$ & $\begin{array}{c}\text { InIrri1 to } \\
\text { InIrri2 }\end{array}$ & $\begin{array}{c}\text { InIrri2 to } \\
\text { PostIrri1 }\end{array}$ & $\begin{array}{c}\text { PostIrri1 to } \\
\text { PostIrri2 }\end{array}$ \\
\hline Calcite & -0.0098 & $/$ & -0.0032 & -0.0025 \\
Dolomite & $/$ & $/$ & $/$ & $/$ \\
Gypsum & 0.0098 & $/$ & 0.0032 & 0.0025 \\
Siderite & 0.0783 & 0.0251 & 0.0259 & 0.0225 \\
$\mathrm{Fe}(\mathrm{OH})_{3}(\mathrm{a})$ & -0.0783 & $/$ & -0.0259 & -0.0200 \\
$\mathrm{FeS}(\mathrm{ppt})$ & $/$ & -0.0251 & $/$ & -0.0025 \\
$\mathrm{CO}(\mathrm{g})$ & -0.0685 & -0.0251 & -0.0227 & -0.0200 \\
$\mathrm{H}_{2} \mathrm{~S}(\mathrm{~g})$ & -0.0098 & 0.0251 & -0.0032 & $/$ \\
\hline
\end{tabular}

Positive and negative phase mole transfers indicate dissolution and precipitation, respectively. "/" indicates no phase transfers.

HS- and produces FeS(ppt) in the end. When irrigation, As from soil water showing a decrease trend (Figure 1) indicates that As was adsorbed directed towards Fe sediments since $\mathrm{Fe}(\mathrm{II})$ in irrigated water was oxidized to Fe(III) (oxyhydr)oxide (Table 1). Thus, the main geochemical processes during irrigation is oxidization of $\mathrm{Fe}$ (II) to $\mathrm{Fe}$ (III) (oxyhydr)oxide and adsorption of As in irrigated water with infiltration.

\section{CONCLUSIONS}

From the hydrochemical properties, sediments results and geochemical modeling, the following characteristics and controlling factors can be inferred.

(1) Irrigation activities would result in the salinization and the accumulation of As in topsoil.

(2) With irrigation on-going, As has decoupled with Fe gradually.

(3) The main geochemical processes indicating from inverse geochemical modeling during irrigation are that $\mathrm{Fe}(\mathrm{II})$ was oxidized to $\mathrm{Fe}$ (III) (oxyhydr)oxide and As was adsorbed from irrigated water with infiltration.

\section{ACKNOWLEDGEMENTS}

The research work was supported by National Natural Science Foundation of China (41372254) and China University of Geosciences (Wuhan).

\section{REFERENCES}

Charlton, S. R. \& Parkhurst, D. L. 2011. Modules based on the geochemical model PHREEQC for use in scripting and programming languages. Comput. Geosci., 37(10): 1653-1663.

Mandal, B.K. \& Suzuki, K.T. 2002. Arsenic round the world: a review. Talanta 58(1): 201-235.

Postma, D., Larsen, F., Thai, N. T., Trang, P. T. K., Jakobsen, R., Nhan, P. Q., along, T.V., Viet, P.H. \& Murray, A.S. 2012. Groundwater arsenic concentrations in vietnam controlled by sediment age. Nat. Geosci. 5(9): 656-661. 